\title{
The Australian PiCTURE
}

\author{
Harold Luntz*
}

Australia faces a climate of change with accident compensation following recent high profile personal injury cases, the collapse of two major health insurers, and the release of the Ipp Committee Report. This paper follows Australia's response to these developments, focusing on New South Wales' initial reform of tort law, and suggests that the current and proposed changes may cause more harm to an already fragile system.

\section{INTRODUCTION}

My paper, "Looking Back at Accident Compensation: An Australian Perspective", 1 presented at the ACC Symposium in August 2002, concluded with the statement: ${ }^{2}$

... all the States have moved to tighten liability for negligence and to limit damages. But retention of the common law seems sacrosanct. The emphasis in many of these 'reforms' is increased 'personal responsibility'. No longer does the Woodhouse call for 'community responsibility' resonate among politicians and the public.

In the context, "retention of the common law" meant retaining the common law system of compensating personal injury through the tort system, which is based essentially on fault, as opposed to introducing a comprehensive no-fault scheme such as the one operating in New Zealand. It was not intended to suggest that the common law would be retained in its developed form; that would have been inconsistent with the tightening of liability and the limits placed on the recovery of damages.

The present paper presents a view of the reasons for the moves towards restriction of liability and damages in personal injury actions in Australia. It briefly sets out the process by which the restrictions have come about. It then draws attention to some of the changes that have been made. At the time of writing this article, that process was still in progress. On 19 February 2004, the Commonwealth Government introduced into the Australian Parliament a Trade Practices

* Professorial Fellow, The University of Melbourne.

1 Harold Luntz "Looking Back at Accident Compensation: An Australian Perspective" (2003) 34 VUWLR 279 .

2 Luntz, above n 1, 292 (footnote omitted). 
Amendment (Personal Injuries and Death) Bill (No 2) 2004 (Cth), providing for caps and thresholds for heads of damages recoverable under many of the provisions of the Trade Practices Act 1974 (Cth), such as those dealing with manufacturers' liability for defective products. The Bill would also change the limitation periods within which to bring such actions. ${ }^{3}$ At the end of February, the Commonwealth Government released a 143-page document reviewing the changes in all the Australian jurisdictions that had already been made and further changes that were proposed. ${ }^{4}$ Despite its length, that document overlooked some of the legislative changes at State level. ${ }^{5}$ The present paper makes no claim to being comprehensive.

This paper attempts to demonstrate how the cost of retaining the common law system in respect of motor accidents, even with limitations on recovery of damages, in New South Wales compares unfavourably with the no-fault system operating in the neighbouring State of Victoria and even more so when compared with the Accident Compensation scheme in New Zealand. Similarly, the cost to employers of workers' compensation in Australia, which often includes the possibility of some access to common law action, is much higher than the cost in New Zealand, where common law action is excluded. This gives New Zealand manufacturers a competitive advantage over their Australian rivals.

\section{REASONS FOR RESTRICTING LIABILITY AND DAMAGES \\ A Perceptions as to Recovery by "Undeserving" Plaintiffs}

In an influential speech delivered on 27 April 2002, ${ }^{6}$ the Chief Justice of New South Wales drew attention to the view expressed by Professor Patrick Atiyah in his book The Damages Lottery, ${ }^{7}$ that the courts had engaged in the practice of "stretching the law" to allow more and more recovery to injured people under the law of negligence. The Chief Justice added that "[t]here may be an equivalent parallel trend, perhaps of even greater practical significance, of 'stretching the facts'". He argued that the test for liability under the law of negligence had become too easy to satisfy since the decision of the Privy Council in Overseas Tankship (UK) Ltd v The Miller Steamship Co Pty Ltd

3 The Bill was enacted and came into force on 13 July 2004.

4 Commonwealth of Australia Reform of Liability Insurance Law in Australia (Commonwealth Treasury, Canberra, 2004) available at <http://www.treasury.gov.au> (last accessed 2 March 2004).

5 For example, it omits reference to the Transport (Highway Rule) Act 2002 (Vic), which restored the immunity of highway authorities from actions for nonfeasance that had been overturned by the High Court of Australia (by a majority of 4:3) in Brodie v Singleton Shire Council (2001) 206 CLR 512.

$6 \quad$ Hon J J Spigelman "Negligence: The Last Outpost of the Welfare State" (2002) 76 ALJ 432.

$7 \quad$ Patrick Atiyah The Damages Lottery (Hart Publishing, Oxford, 1997); reviewed by Harold Luntz (1997) 5 TLJ 287. 
(The Wagon Mound (No 2)), ${ }^{8}$ which was subsequently accepted by the High Court of Australia in Wyong Shire Council $v$ Shirt. ${ }^{9}$ This view was later echoed in the High Court of Australia itself by McHugh J, who said: ${ }^{10}$

[I]n the light of 35 years experience, the decision in The Wagon Mound (No 2) and the ... passage [in Wyong] in particular appear to me to have been an unfortunate development in the law of negligence. I think that the time has come when this Court should retrace its steps so that the law of negligence accords with what people really do, or can be expected to do, in real life situations. Negligence law will fall - perhaps it already has fallen - into public disrepute if it produces results that ordinary members of the public regard as unreasonable.

Much of the blame for this was laid at the door of judges. It is ironic that two cases where the public apparently felt that the law had gone too far in allowing recovery were decisions of juries, which are, or should be, representative of the views of ordinary people. One was a case in which a young man dived into a shallow canal and broke his neck. He made his dive from the boundary fence of the house of a friend's parents. The jury held that he was entitled to recover 70 per cent of his damages from the occupiers of the property, because the existence of the fence without any warning sign was perceived as an invitation to use it as a diving platform. The decision of the jury was set aside by the Queensland Court of Appeal and the High Court refused leave for a further appeal. $^{11}$

Similarly, a jury found the local council liable when a swimmer on Sydney's famous Bondi beach dived into a wave and broke his neck. The New South Wales Court of Appeal unanimously held that there was no evidence on which the jury could have found that the council was negligent in failing to warn of the dangers inherent in swimming in the surf. A majority of the Court also held that there was no evidence that the council was negligent on the day in the placement of the flags between which swimmers were advised to swim. ${ }^{12}$ Ironically Spigelman CJ was the dissenting member of the Court of Appeal on this occasion. In this instance, the High Court of Australia has given leave for a further appeal. ${ }^{13}$

Whether or not the public at large is truly concerned that people are able to recover compensation in circumstances like these without proof of "real" negligence on the part of the

8 Overseas Tankship (UK) Ltd v The Miller Steamship Co Pty Ltd (The Wagon Mound (No 2)) [1967] 1 AC $617(\mathrm{PC})$.

$9 \quad$ Wyong Shire Council v Shirt (1980) 146 CLR 40, 47 Mason J.

10 Tame v New South Wales; Annetts v Australian Stations Pty Ltd (2002) 211 CLR 317, para 101 McHugh J.

11 Borland v Makauskas [2000] QCA 521 (Qld CA); (12 October 2001) HCA B6/2001.

12 Waverley Municipal Council v Swain (2003) Aust Torts Reps 81-694; [2003] NSWCA 61.

13 Swain v Waverley Municipal Council [2003] HCATrans 500. 
defendants, there is no doubt that many politicians at least express outrage when someone who was engaged in illegal activity at the time of injury is held entitled to succeed in a tort action. The mere fact that a plaintiff was acting illegally at the time of injury does not at common law disentitle them to compensation. In Henwood v Municipal Tramways Trust, Latham CJ said: ${ }^{14}$

[T] here is no general principle of English law that a person who is engaged in some unlawful act is disabled from complaining of injury done to him by other persons, either deliberately or accidentally. He does not become caput lupinum [an outlaw; literally, a wolf's head]. Other persons still owe to him a duty to take care, the extent of that duty being determined by the circumstances of the case which create the duty.

One instance where the application of this principle provoked popular outrage involved an intoxicated teenager who was refused entry to a night club at a hotel. Seeking a way in, he went round to the back of the premises, scaled a wall and entered the residence of the licensee of the hotel. The licensee heard him and approached with an iron bar. The teenager cowered in the corner of the laundry, but the licensee struck him over the head with the iron bar, causing serious injury. A District Court judge awarded him damages of nearly $\$ 50,000$ and his mother $\$ 18,500$ for nervous shock which she sustained when she saw his injuries. ${ }^{15}$ Immediately, politicians called for amendment of the law to prevent a repetition of such an award. ${ }^{16}$ As we shall see later, this issue was taken up in the legislation that swept Australia in the last two years. ${ }^{17}$

Similar views have been expressed in England, where the case of Tony Martin has become a cause célèbre. Martin was convicted of murder, reduced on appeal to manslaughter, when he shot and killed a burglar who was breaking into his lonely farmhouse. Another of the burglars, who was injured and not killed, threatened to sue Martin. ${ }^{18}$ Although this was not proceeded with, the Home Secretary announced that he would introduce legislation to prevent any such actions. ${ }^{19}$ This would

14 Henwood v Municipal Tramways Trust (1938) 60 CLR 438, 446 Latham J. Nevertheless, the High Court of Australia has struggled to lay down a principle as to when joint illegality should prevent a duty of care from arising: see Smith v Jenkins (1970) 119 CLR 397; Progress \& Properties Ltd v Craft (1976) 135 CLR 651; Jackson v Harrison (1978) 138 CLR 438; Gala v Preston (1991) 172 CLR 243.

15 Ellen Connolly "Court Awards Intruder \$50,000 for Pub Beating" (30 August 2002) The Age Melbourne 3. The award was subsequently set aside on appeal and a new trial ordered because of procedural irregularities at the hearing: Peakhurst Inn Pty Ltd v Fox [2004] NSWCA 74.

16 See for example Deutsche Presse-Agentur "Drunken Lout Hits Compensation Jackpot in Australia" (30 August 2002) Butterworths Legal Express Sydney. See also Larissa Dubecki "Nats to Abolish Right-to-Sue Law" (7 November 2002) The Age Melbourne 9.

17 Civil Liability Act 2002 (NSW), ss 51-54.

18 David Brown "Jailed Farmer Sued by Burglar" (24 December 2002) The Times London 7.

19 Adam Fresco "Burglars will Lose Right to Sue" (17 May 2003) The Times London 11. 
seem to pre-empt any recommendations that might emerge from a review of the law currently being undertaken by the Law Commission, on which it issued a consultation paper some time ago. ${ }^{20}$

The issue of compensation for people engaged in illegal activities has, of course, provoked strong feelings in New Zealand too. In New Zealand, section 92 of the Accident Compensation Act 1982 introduced a provision permitting the Accident Compensation Corporation to decline, in whole or in part, to give rehabilitation assistance and pay compensation to a person convicted and sentenced to imprisonment, where "it would be repugnant to justice" to provide such benefits. The interpretation of this provision was considered in ACC v Curtis, ${ }^{21}$ where guidelines were laid down. ${ }^{22}$ The Injury Prevention, Rehabilitation and Compensation Act 2001, now vests the power to determine that benefits should not be paid on this ground in a District Court and lists relevant matters to be taken into account. ${ }^{23}$

When the Australian Woodhouse proposals were under consideration by the Senate's Constitutional and Legal Affairs Committee, ${ }^{24}$ one Senator dissented vigorously from proposals to allow compensation to be payable in such circumstances. ${ }^{25}$

\section{B Alleged Development of "Blame Society"}

In the speech referred to above, ${ }^{26}$ Spigelman $\mathrm{CJ}$ also drew attention to certain remarks of Thomas JA, a long-serving judge of the Queensland Supreme Court, in Lisle v Brice. ${ }^{27}$ In this case, Thomas JA agreed with the other members of the Court in upholding the decision of the trial judge to award damages for the support of the wife and children of a man who committed suicide three years after suffering relatively minor physical injuries in a motor accident. His Honour regarded himself as constrained by authority to do so. But he drew attention to several areas of the law of negligence in which recovery of damages had been expanded and continued: ${ }^{28}$

20 Law Commission for England and Wales The Illegality Defence in Tort (Consultation Paper No 160, Her Majesty's Stationery Office, London, 2001).

21 ACC v Curtis [1994] 2 NZLR 519 (CA).

22 See Stephen Todd "Privatization of Accident Compensation: Policy and Politics in New Zealand" (2000) 39 Washburn LJ 404, 461-3.

23 Injury Prevention, Rehabilitation, and Compensation Act 2001, s 122.

24 See Luntz, above n 1, 288-9.

25 See Senator Wright "Addendum" in Senate Standing Committee on Constitutional and Legal Affairs Clauses of the National Compensation Bill 1974 (Australian Government Publishing Service, Canberra, 1975) 212.

26 Spigelman, above $\mathrm{n} 6$.

27 Lisle v Brice [2002] 2 Qd R 168 (Qld CA).

28 Lisle v Brice, above $\mathrm{n} 27$, paras 4-5 Thomas JA. 
The generous application of these rules is producing a litigious society and has already spawned an aggressive legal industry. I am concerned that the common law is being developed to a stage that already inflicts too great a cost upon the community both economic and social.

In a compensation-conscious community citizens look for others to blame. The incentive to recover from injury is reduced. Self-reliance becomes a scarce commodity. These are destructive social forces. Also much community energy is wasted in divisive and non-productive work ... I fear we are developing a creature we can no longer control.

On his retirement from the bench soon afterwards, the former judge repeated these views. ${ }^{29}$ They have been widely echoed in the community, most vigorously as a result of a recent decision of the High Court of Australia. In Cattanach v Melchior, ${ }^{30}$ by a majority of 4:3, the High Court held that the parents of a healthy child born as a result of the negligent failure of a medical practitioner to give appropriate advice were entitled to recover the reasonable costs of maintaining the child after birth. The long detailed judgments of members of both the majority and minority were largely ignored in the outpouring of criticism by politicians and others. Much of that criticism stemmed from the view that the birth of healthy children should always be regarded as a blessing. ${ }^{31}$ However, the critics who were prepared to concede that parents who had deliberately taken steps to limit the size of their family might not treat the birth of a healthy child entirely as a benefit, focussed on what was seen as the tendency to look for someone to blame for any of the misfortunes that befall all of us. $^{32}$

Whatever the basis of the criticism of the decision in Cattanach $v$ Melchior, ${ }^{33}$ at least two legislatures rapidly reacted by enacting legislation which, in different terms, prohibits the courts from awarding damages for the cost of bringing up a healthy child. ${ }^{34}$

29 See Dr M White QC "People in the Law - Mr Justice J B Thomas AM" (2003) 77 ALJ 22.

30 Cattanach v Melchior [2003] HCA 38; (2003) 199 ALR 131.

31 Compare the dissenting judgment of Meagher JA in the earlier case of CES v Superclinics (Australia) Pty Ltd (1995) 38 NSWLR 47 (NSWCA).

32 See, for example, the "reservations" expressed in the Editorial "Babies, Bungles and Compensation" (18 July 2003) The Age Melbourne: "the case is another example of the trend to seek compensation for the unforeseen contingencies that will always be part of life".

33 Cattanach v Melchior, above n 30.

34 Civil Liability Act 2003 (Qld), ch 2 Pt 5, inserted by the Justice and Other Legislation Amendment Act 2003 (Qld), s 41; Civil Liability Act 2002 (NSW), Pt 11, inserted by the Civil Liability Amendment Act 2003 (NSW), sch 1, cl 6; Civil Liability Act 1936 (SA), s 67, inserted by the Law Reform (Ipp Recommendations) Act 2004 (SA). 


\section{Awards of "Excessive" Damages}

In November 2001, the New South Wales Supreme Court awarded damages of A\$14,202,042 to a 22-year-old woman, Calandre Simpson, who had been severely injured at birth. ${ }^{35}$ This sent shock waves through the medical community on two counts.

First, it reminded practitioners that under the limitation of actions legislation then in force in many Australian jurisdictions, claims by minors could be instituted three or even six years after they obtained their majority, which itself might be 18 years after the acts constituting negligence. Many medical indemnity insurers had not made provision for incurred, but not reported claims (IBNRs), where liability would be sheeted home so many years later. Practitioners who did not have "claims incurred" cover at the time of the negligent acts, but relied on "claims made" policies for cover at later times, might find that the claims were actually made after they had retired and no longer had cover of any sort. Warnings against the inadequate provision for IBNRs and reliance on "claims made" policies for cover had been given a few years earlier in a Commonwealth report. ${ }^{36}$ However, the body that inquired into the issue had been appointed by one government, but by the time it produced this report another government was in power and its recommendations were ignored.

Secondly, the medical community appeared to be unaware of the consequences of its own success in keeping severely disabled people alive for much longer periods than in the past. When this was coupled with increased sophistication in recognition of the needs for care of such people and the translation of those needs into monetary compensation, damages awards inevitably became much higher than in the past. In the case of Calandre Simpson, the judge was faced with what he described as a "battle royal" between the statisticians and clinicians in predicting how long she was likely to live. He concluded that she would live 51 years from her 22nd birthday and proceeded to make his calculations of the damages to meet her needs for care on the basis of 50.67 years from the date of judgment. Furthermore, he considered the damages to be awarded to her under no fewer than 31 heads, nearly all of which were contested. Although he did not award damages under every one of those heads, by far the largest head was for the cost of future attendant care, which came to over A $\$ 6.5$ million. Subsequently, the New South Wales Court of Appeal reduced this particular head of damages to just under $\mathrm{A} \$ 5$ million and the total award to the vicinity of $\mathrm{A} \$ 11.2$ million. ${ }^{37}$

Of course, whatever the precise figure, it is bound to be wrong, since it is almost certain that the assumptions made as to the plaintiff's lifespan and the costs that she will incur will prove to be wrong, so that either her estate will receive a windfall or she will not be fully compensated in the

35 Simpson v Diamond [2001] NSWSC 925; Simpson v Diamond (No 2) [2001] NSWSC 1048 Whealy J.

36 Commonwealth Department of Human Services and Health, Final Report of the Review of Professional Indemnity Arrangements for Health Care Professionals, Compensation and Professional Indemnity in Health Care (Australian Government Publishing Service, Canberra, 1995) paras 9.81-9.82.

37 Diamond v Simpson (No 1) (2003) Aust Tort Reps 81-695; [2003] NSWCA 67. 
end. ${ }^{38}$ But it is the trial judge's figure of over A $\$ 14$ million that stuck in the minds of many of those who were shocked by the decision. An even higher award of A $\$ 16,347,477.91$ made at about the same time in a motor accident case, ${ }^{39}$ which survived an appeal, ${ }^{40}$ has not been so frequently pointed to as an illustration of excessive damages, presumably because motor insurers were better prepared and various caps and limitations on damages were already in place in such cases.

\section{Collapse of Two Major Insurers}

Increased litigation, more successful claims and higher awards of damages have all been blamed for an alleged "crisis" that occurred in the availability and affordability of public liability and medical indemnity insurance in Australia in 2001-02. For instance, a report to the Insurance Issues Working Group of Heads of Treasuries stated that "all jurisdictions have experienced an increase in the size of bodily injury claims in excess of normal inflation [and] the rate of increase appears to be higher since the mid $1990 \mathrm{~s} " .^{41}$ On the other hand, there are those who claim that there has been no increase in litigation. ${ }^{42}$ The immediately precipitating factor in the steep increase in insurance

38 See Lim v Camden and Islington Area Health Authority [1980] AC 174, 183 (HL) Lord Scarman.

39 Palmer $v$ Roads and Traffic Authority [2002] NSWSC 34 Wood CJ.

40 Roads and Traffic Authority of NSW v Palmer (2003) Aust Torts Reps 81-693; [2003] NSWCA 58.

41 Trowbridge Consulting and Deloitte Touche Tohmatsu Public Liability Insurance: Practical Proposals for Reform (Canberra, 2002) x <http://www.treasury.gov.au> (last accessed 8 March 2004) ["Public Liability Insurance: Practical Proposals for Reform"]. See also the earlier report, Trowbridge Consulting and Deloitte Touche Tohmatsu Public Liability Insurance: Analysis for Meeting of Ministers 27 March 2002 (Canberra, 2002) <http://www.treasury.gov.au> (last accessed 8 March 2004) ["Public Liability Insurance: Analysis for Meeting of Ministers 27 March 2002"]. Other sources that seek to ascertain the causes include Senate Economics References Committee A Review of Public Liability and Professional Indemnity Insurance (Parliament of Australia, Canberra, 2002) <http://www.aph.gov.au> (last accessed 8 March 2004); Australian Competition and Consumer Commission Insurance Industry Market Pricing Review (Canberra, 2002) <http://www.accc.gov.au> (last accessed 19 January 2004) ["Insurance Industry Market Pricing Review"]; Australian Competition and Consumer Commission Second Insurance Industry Market Pricing Review (Canberra, 2002) <http://www.accc.gov.au> (last accessed 24 November 2003) ["Second Insurance Industry Market Pricing Review"]; D Kehl Liability Insurance Premium Increases: Causes and Possible Government Responses (Current Issues Brief No 10 2001-02, Commonwealth of Australia, Department of the Parliamentary Library, Canberra, 2002) <http://www.aph.gov.au> (last accessed 19 January 2004). Some of these are considered by Peter Cane "Reforming Tort Law in Australia: A Personal Perspective" (2003) 27 MULR 649, 656-63. See also J J Spigelman "Negligence and Insurance Premiums: Recent Changes in Australian Law" (2003) 11 TLJ 291 ["Negligence and Insurance Premiums"]; Peter Underwood "Is Ms Donoghue's Snail in Mortal Peril?" (2004) 12 TLJ 39.

42 Rob Davis "The Tort Reform Crisis" (2002) 25 UNSWLJ 865, 897, citing Productivity Commission Annual Report 2000-2001 (Productivity Commission, Canberra, 2002) table 9A. However, no such table appears in this report and the source of the table has not been able to be traced. See also Peter Cashman "Tort Reform and the Medical Indemnity 'Crisis"' (2002) 25 UNSWLJ 888; compare AHMAC Legal Process Reform Group (Marcia Neave, Chairperson) Responding to the Medical Indemnity Crisis: An Integrated Reform Package (The Australian Health Ministers Advisory Council, Melbourne, 2002) $<$ http://www.health.act.gov.au> (last accessed 8 November 2002). 
premiums that undoubtedly did occur was the collapse of two major insurers, the HIH insurance group and United Medical Protection (UMP).

HIH was probably the largest public liability insurer in Australia, having about 30 per cent share of the market. For some years prior to its collapse, it aggressively sought market share, cutting premiums drastically and making insufficient provision for claims. On its liquidation early in 2001, it left a deficiency of between $\mathrm{A} \$ 3$ billion and $\mathrm{A} \$ 7$ billion. An interesting sidelight on the collapse was that litigation proceeding in the courts at the time was reportedly adjourned because plaintiffs did not know whether they would recover any damages, even if they were successful in obtaining judgment, and the lawyers involved did not know whether they would be paid for their services. ${ }^{43}$ After a 15-month inquiry, a Royal Commission into the collapse produced a massive three-volume report which demonstrated a long history of mismanagement and insufficient reserves, but did not provide a final figure for the losses likely to be sustained. ${ }^{44}$ It made 61 "policy recommendations", designed to prevent the collapse of an insurer in the future.

UMP was by far the largest medical indemnity organisation in Australia, providing indemnity protection for about 60 per cent of medical practitioners. It went into provisional liquidation in April 2002. Unlike $\mathrm{HIH}$, it eventually emerged from provisional liquidation and resumed business. This was largely because of intervention by the Federal Government, which provided a series of guarantees and mechanisms for dealing with the problem of IBNRs. In law, most Medical Defence Organisations (MDOs) were not technically insurers, since they reserved a discretion whether to pay claims and very occasionally exercised that discretion so as to refuse to indemnify a member. Most doctors were unaware of this, but it meant that the MDOs escaped the government regulation of insurers and enabled them not to make provision in their reserves for IBNRs. Of course, the fact that $\mathrm{HIH}$ was regulated did not prevent its collapse, but at least theoretically it was supposed to make adequate provision for the "long tail" involved in liability insurance, whereas UMP was not required to do so.

\section{E Consequences of Collapse of Insurers and Other Factors}

Once the major insurers of public liability and medical indemnity collapsed, as already noted in relation to $\mathrm{HIH}$, enforcement of existing claims by injured victims became doubtful. Other insurers, whose premium-setting had for years needed to compete with the unsustainable level set by $\mathrm{HIH}$, reverted to more realistic pricing of their products and probably sought to recoup some of their

43 Darrin Farrant "Lawyers Facing Loss of Millions" (17 May 2001) The Age Melbourne 8.

44 See HIH Royal Commission Report 2003 <http://www.hihroyalcom.gov.au> (last accessed 8 March 2004) The Report in fact commenced with the statement that on the date formal winding-up commenced, 27 August 2001, "the deficiency of the group was estimated to be between $\$ 3.6$ billion and $\$ 5.3$ billion. If the ultimate shortfall is anywhere near the upper end of that range, the collapse of HIH will be the largest corporate failure Australia has endured to date". Subsequent estimates take the losses beyond the top of that range. 
losses during the unprofitable years. There is also a view, disputed by some, that the effects of 11 September 2001 on the worldwide reinsurance market also forced insurers to increase their premiums. Another factor may have been the fall in the world's stockmarkets. In years when the stockmarket is rising insurers can afford to set off underwriting losses against their investment gains, but they are unable to do so when their investments are falling in value. ${ }^{45}$

Whatever the causes, there is no doubt that premiums for both public liability and medical indemnity sky-rocketed, making many activities unaffordable. The Senate Economics References Committee's report, A Review of Public Liability and Professional Indemnity Insurance, ${ }^{46}$ includes Appendix 4 which contains over two pages of examples of premium increases put forward in a submission from the New South Wales Department of Sport and Recreation. These include a 100 per cent increase for a golf tournament, from $\mathrm{A} \$ 15,000$ to $\mathrm{A} \$ 30,000$; a parachute association's increase from $\mathrm{A} \$ 127,000$ to $\mathrm{A} \$ 1.1$ million; and cancellation of events like go-kart races, surf festivals and many others because of huge increases in premiums. Other organisations complained that public liability insurance was impossible to obtain at any price. A list of aspects of everyday life that were cancelled or threatened with closure referred to community festivals; carnivals; art shows; agricultural shows; sporting events of all kinds; country fetes; music concerts; Christmas carols; street parades; theatre performances; community halls; and every manner of outdoor event. The body that compiled this list was "informed that some schools and kindergartens are not able to offer the facilities they would wish and some have had to close". It saw these as "merely some examples of the way in which the fabric of everyday life has been harmed". ${ }^{47}$ It noted that the "effect is most strongly felt in the country". 48

The collapse of UMP obviously did not have the same drastic direct effects. The immediate consequences were that doctors threatened to go on strike. They did this repeatedly. ${ }^{49}$ Hospitals experienced difficulties with staffing. ${ }^{50}$ Again, it may have been that the country was more affected than the cities.

45 See generally Public Liability Insurance: Practical Proposals for Reform, above n 41; Public Liability Insurance: Analysis for Meeting of Ministers 27 March 2002, above n 41; Senate Economics References Committee, above n 41; Insurance Industry Market Pricing Review, above n 41; Second Insurance Industry Market Pricing Review, above n 41; Kehl, above n 41; Cane, above n 41; "Negligence and Insurance Premiums", above n 41; Underwood, above n 41.

46 Senate Economics References Committee, above $\mathrm{n} 41$.

47 Commonwealth of Australia, Panel of Eminent Persons Review of the Law of Negligence Report (Australian Government Publishing Service, Canberra, 2002) para 1.34 ["Ipp Committee Report"].

48 Ipp Committee Report, above n 47, para 1.35.

49 See Harold Luntz "Guest Editorial: Medical Indemnity and Tort Law Reform" (2003) 10 JLM 385.

50 See for example Ruth Pollard and Ben Wyld "Doctors at a Premium in the Litigation Era" (12 August 2003) Sydney Morning Herald Sydney 1. 


\section{GOVERNMENT INTERVENTION}

The Federal and State governments were compelled to intervene in this state of affairs. First, they needed to protect people with existing claims. Secondly, they needed to provide organisations and medical practitioners with protection against claims arising from past events. Thirdly, they had to try to ensure that there would be affordable insurance available in the future.

Despite the current Federal Government's ideological opposition to interference with market forces, it stepped in to meet the first of these objectives. The Parliament appropriated A $\$ 640$ million to meet claims arising out of the collapse of the HIH group of companies. ${ }^{51}$ It also amended the Income Tax Assessment Act 1997 (Cth) to make provision for what it expressly called the "HIH rescue package". ${ }^{52}$ In relation to UMP, it immediately announced a guarantee of $\$ 35$ million to meet IBNRs, and later backed this up with legislation. ${ }^{53}$ The Federal Government has been negotiating with doctors ever since in relation to the second and third objectives. This has led to the passing of numerous pieces of legislation as the demands of the doctors increased. ${ }^{54}$ The ultimate cost to taxpayers is likely to run into hundreds of millions of dollars.

Some of the States also took action to protect claimants left unprotected by the collapse of HIH. In New South Wales the Legal Profession Practice Act 1987 (NSW) was amended to provide for special contributions and levies. ${ }^{55}$ As was stated when the amending Bill was introduced, the first purpose of the new legislation was "to ensure that people who have claims against solicitors which are affected by the collapse of $\mathrm{HIH}$ insurance receive payment for their claims". ${ }^{56}$ In Victoria, where HIH was the major insurer of builders, the House Contracts Guarantee (HIH) Act 2001 (Vic) was enacted to provide for payment by the State of claims, subject to assignment of rights against $\mathrm{HIH}$, which would almost certainly prove to be worthless.

51 Appropriation (HIH Assistance) Act 2001 (Cth).

52 See Taxation Laws Amendment Act (No 6) 2001(Cth), sch 5.

53 Medical Indemnity Act 2002 (Cth).

54 For example, Medical Indemnity (IBNR Indemnity) Contribution Act 2002 (Cth); Medical Indemnity Amendment Act 2003 (Cth); Medical Indemnity (Prudential Supervision and Product Standards) Act 2003 (Cth); Medical Indemnity (Prudential Supervision and Product Standards) (Consequential Amendments) Act 2003 (Cth); Medical Indemnity (IBNR Indemnity) Contribution Amendment Act 2003 (Cth).

55 See Legal Profession Practice Act 1987 (NSW), s 46A, inserted by Legal Profession Amendment (Professional Indemnity Insurance) Act 2001 (NSW)

56 Mr Crittenden on behalf of Mr Debus (25 June 2001) Legislative Assembly Hansard (NSW) 15237. 
To provide community groups and local councils with affordable cover in the future, various State governments set up insurance pools. ${ }^{57}$ A year later the problem had not been solved. ${ }^{58}$

\section{TORT LAW REFORM}

\section{A Initial Legislation and Proposals}

Meanwhile, the New South Wales government saw the solution in "tort law reform". Even before the medical indemnity "crisis" developed, it enacted the Health Care Liability Act 2001 (NSW). Among the objects stated in the Act were: ${ }^{59}$

$[\mathrm{T}] \mathrm{o}$ keep the costs of medical indemnity premiums sustainable, in particular by limiting the amount of compensation payable for non-economic loss in cases of relatively minor injury, while preserving principles of full compensation for those with severe injuries involving ongoing impairment and disabilities.

The hypocrisy of claiming that the Act preserved "full compensation for those with severe injuries" is demonstrated by section 11, which increased the discount rate for future loss from 3 per cent to 5 per cent. This has the effect of reducing the compensation to those with "ongoing impairment and disabilities" and makes it much more unlikely that the lump sum awarded to them will enable them to meet their needs for care over the estimated period of their lifespan.

At the same time as the new legislation introduced limits on the damages recoverable by victims of medical negligence, it provided a further concession to the medical profession. There is no recorded case of a medical practitioner being held liable for negligence in providing help in an emergency. ${ }^{60}$ However, practitioners claimed that the fear of being sued often influenced them not to render aid. Queensland had provided immunity from liability in such circumstances for many years, ${ }^{61}$ but no other State had introduced similar "Good Samaritan" legislation until Part 4 (sections 26 and 27) of the Health Care Liability Act 2001 (NSW) did so. It provided that if a health professional rendered assistance in an emergency in good faith and without expectation of fee or reward, then they "cannot be subject personally to any civil action, liability, claim or demand in

57 For example, Linda Morris "Insurance Giants go for Goodwill with Local Groups" (6 September 2002) Sydney Morning Herald Sydney 7; CCH News Headlines "Community Insurance Fund Established in Western Australia" (CCH Australia, 2003) < http://www.cch.com.au> (last accessed 7 January 2003).

58 Linda Morris "Community Groups Hit as Premiums Soar" (15 July 2003) Sydney Morning Herald, Sydney 4.

59 Health Care Liability Act 2001 (NSW), s 3(1)(b).

60 New South Wales boasts one unique case of a doctor being held liable for failing to go to the aid of a child in an emergency situation: Lowns $v$ Woods (1996) Aust Torts Reps 81-376 (NSWCA). The legislation would offer no protection to the doctor in such a case.

61 Voluntary Aid in Emergency Act 1973 (Qld), re-enacted in Law Reform Act 1995 (Qld), Pt 5. 
respect of the provision of that health care". Later, the expert panel set up to review the law of negligence expressed the view that despite the anxiety on the part of medical practitioners, the absence of such legislation elsewhere had not led to any insurance difficulties. The panel thought it "unnecessary and, indeed, undesirable ... to exempt good Samaritans entirely from the possibility of being sued for negligence". ${ }^{62}$ Nevertheless, such legislation has subsequently been enacted in most other jurisdictions, though the wording varies. ${ }^{63}$

Similar calls were made all over the country for protection for "volunteers" who work for community organisations without reward. Again the expert panel, which as we shall see was set up deliberately to rein in both liability and damages, commented: ${ }^{64}$

The Panel is not aware of any significant volume of negligence claims against volunteers in relation to voluntary work, or that people are being discouraged from doing voluntary work by the fear of incurring negligence liability. The Panel has decided to make no recommendation to provide volunteers as such with protection against negligence liability.

In the rush of legislation that followed its report, this recommendation was ignored and people doing community work were made immune from liability. In most jurisdictions, however, liability was simply shifted from the volunteers to the organisation for whom they provided the voluntary work. $^{65}$

Towards the middle of 2002, the New South Wales Parliament enacted the Civil Liability Act 2002 (NSW). This contained similar provisions to the Health Care Liability Act with regard to limitation of damages, which it repealed in this respect. It extended the 5 per cent discount rate to all personal injury claims. The government then released for public debate the draft Civil Liability Amendment (Personal Responsibility) Bill 2002, which gave increased protection to, among others, recreational service providers. It proposed to prevent recovery where there was an obvious danger and where the victim was committing a crime at the time of injury. It also provided for drastic reductions of damages where the victim was intoxicated. There was much discussion at the time regarding the need to return to a "more principled" approach to the law of negligence, which had been called for by the Chief Justice of New South Wales in the paper referred to above. ${ }^{66}$ What this

62 Ipp Committee Report, above n 47, para 7.21

63 Civil Liability Act 1936 (SA), s 74; Wrongs Act 1958 (Vic), Pt VIA; Civil Liability Act 2002 (WA), Pt 1D; Civil Law (Wrongs) Act 2002 (ACT), s 5; Personal Injuries (Liabilities and Damages) Act 2003 (NT), s 8.

64 Ipp Committee Report, above n 47, para 11.21.

65 Commonwealth Volunteers Protection Act 2003 (Cth); Civil Liability Act 2002 (NSW), Pt 9; Civil Liability Act 2003 (Qld), ss 38-44; Volunteers Protection Act 2001 (SA); Civil Liability Act 2002 (Tas), Pt 10; Wrongs Act 1958 (Vic), Pt IX; Volunteers (Protection from Liability) Act 2002 (WA); Civil Law (Wrongs) Act 2002 (ACT), Pt 2.2; Personal Injuries (Liabilities and Damages) Act 2003 (NT), s 7.

66 Spigelman, above $\mathrm{n} 6$. For a forum putting forward a range of views on the need for reform at the time, see (2002) 25 UNSWLJ 808-903. One contribution to the forum was by Stephen Todd "Negligence Liability for 
Bill proposed instead was to introduce a range of unprincipled exceptions to the one general principle that the law of negligence contains, Lord Atkin's "neighbour principle" put forward in Donoghue $v$ Stevenson, that "[y]ou must take reasonable care to avoid acts or omissions which you can reasonably foresee would be likely to injure your neighbour". ${ }^{67}$

\section{B Establishment of Ipp Committee}

New South Wales saw itself as providing, in the Civil Liability Amendment (Personal Responsibility) Bill 2002, a model which it expected to be implemented in other States. However, in the meantime, the Commonwealth Treasury had been active in convening meetings of treasury ministers from all governments in Australia. A meeting held on 27 March 2002 was presented with a report on the supposed crisis written by actuaries and accountants. ${ }^{68}$ This was followed by a report by the same two firms to a meeting of an insurance working group of Heads of Treasuries at the end of May. Quoting from the paper by Spigelman CJ on the "stretching" of the law of negligence and the need for a more principled approach, ${ }^{69}$ this latter report recommended the establishment of a review of the law of negligence to be conducted by a panel of four "eminent persons". It suggested that these might be "a retired judge, an academic lawyer, a practical barrister and, say, a pragmatist with a social sciences background ... with the time to devote and the knowledge and interest to tackle the challenge". ${ }^{70}$

The proposal for a "principle-based review of the law of negligence" to be conducted by a panel of four eminent persons was accepted, and such a panel was appointed. However, instead of a retired judge, a serving judge, Justice David Ipp, formerly of Western Australia, but then acting on the Court of Appeal of the New South Wales Supreme Court and subsequently permanently appointed to that Court, was made chair of the committee. The academic lawyer was Professor Peter Cane. The other two members were a surgeon, Associate Professor Don Sheldon, and a long-time local councillor and mayor, Mr Ian McIntosh. There were no women on the panel.

The panel was not given the time needed to conduct a proper review. Its terms of reference were announced on 2 July 2002. The panel's report was required in two parts, the first by 30 August 2002

Personal Injury: A Perspective from New Zealand" (2002) 25 UNSWLJ 895. The present writer also called for consideration of a New Zealand-type solution: Harold Luntz "Reform of the Law of Negligence: Wrong Questions - Wrong Answers" (2002) 25 UNSWLJ 836.

67 Donoghue v Stevenson [1932] AC 562, 580 (HL) Lord Atkin.

Public Liability Insurance: Analysis for Meeting of Ministers 27 March 2002, above n 41.

69 See Spigelman, above $\mathrm{n} 6$.

70 Public Liability Insurance: Practical Proposals for Reform, above n 41, 27. 
(less than two months later), and the second by 30 September 2002 (less than three months later). Significantly, the terms of reference were introduced by a preamble, which read: ${ }^{71}$

The award of damages for personal injury has become unaffordable and unsustainable as the principal source of compensation for those injured through the fault of another. It is desirable to examine a method for the reform of the common law with the objective of limiting liability and quantum of damages arising from personal injury and death.

The terms of reference themselves made it clear that the assumptions contained in this preamble were unchallengeable and that the panel had in effect to devise ways of limiting liability and damages, but within the law of negligence. ${ }^{72}$ In any event, the time frame given to the panel made it impossible for it to test the assumptions made in the terms of reference. It had to ignore existing empirical evidence and could not conduct any empirical studies of its own.

The panel did receive submissions arguing for a solution in terms of no-fault schemes of various types, but it held that consideration of such a change was outside its terms of reference. ${ }^{73}$

\section{Evidence of Efficiency of No-fault}

Had the Ipp Committee been able to look at the empirical evidence of the functioning of the tort-insurance system as compared to a no-fault scheme, it would have found a comparison ready to hand. Despite a strong recommendation from its Law Reform Commission in 1984 for it to implement a pure no-fault motor accident scheme, ${ }^{74}$ New South Wales has continued to operate a fault system coupled with compulsory third-party motor vehicle insurance for bodily injury. Several times it has placed thresholds and caps on the damages recoverable,${ }^{75}$ but the costs of insuring the average motor vehicle in Sydney has been subject to severe fluctuations and steep increases. In contrast, Victoria implemented the recommendations of the New South Wales Law Reform Commission in 1986, though political compromises required to obtain the consent of the upper house of the legislature meant that the common law was retained to a limited extent for "serious" injury. ${ }^{76}$ At the time of the Ipp Committee report, the Australian Competition and Consumer Commission produced a report on insurance pricing that included an investigation of the effect on premiums of privatising the compulsory third-party motor vehicle insurance market in New South

71 Ipp Committee Report, above n 47, ix.

72 For reflections on the task of the panel by the academic member, see Cane, above n 41 .

73 Ipp Committee Report, above n 47, para 1.21.

74 New South Wales Law Reform Commission "Report on a Transport Accidents Scheme for New South Wales" (LRC 43, Sydney, 1984).

75 Motor Vehicles (Third Party Insurance) Act 1942 (NSW), Pt IIIA; Motor Accidents Act 1988 (NSW), Pt 6; Motor Accidents Compensation Act 1999 (NSW), Pt 5.

76 Transport Accident Act 1986 (Vic). 
Wales. A graph it prepared used the Victorian metropolitan levy by the monopoly insurer, the Transport Accident Commission, as a benchmark. It is as follows: ${ }^{77}$

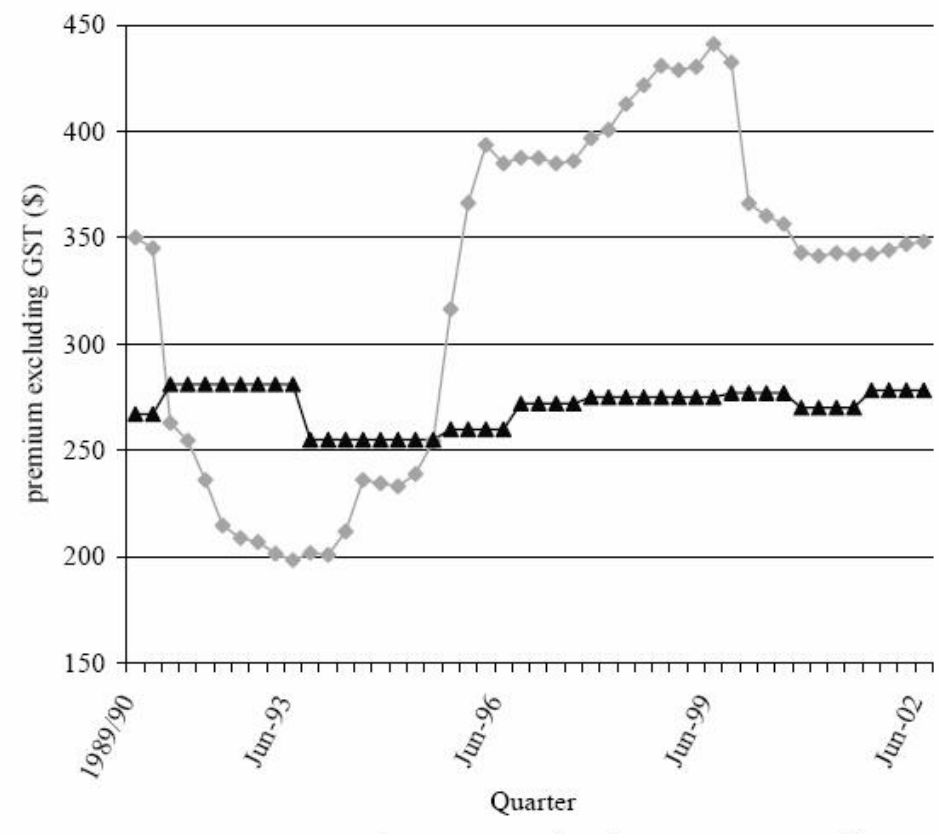

$\rightarrow$ NSW - Metro Class $1 \rightarrow$ Vic Class 10 - Metropolitan

In tabular form, we can compare the New South Wales, Victorian and New Zealand costs for motorists as follows:

\begin{tabular}{|l|l|l|}
\hline Jurisdiction & \multicolumn{1}{|c|}{ System } & \multicolumn{1}{|c|}{$\begin{array}{c}\text { Annual metropolitan average } \\
\text { premium 2002 }\end{array}$} \\
\hline NSW & Common law fault with damages caps & $\begin{array}{l}\sim \mathrm{A} \$ 350 \text { (had been as high as } \\
\$ 440)\end{array}$ \\
\hline Victoria & $\begin{array}{l}\text { Mixed: no-fault with capped residuary } \\
\text { common law fault for "serious injury" }\end{array}$ & $\mathrm{A} \$ 315$ \\
\hline New Zealand & Comprehensive no-fault & $\begin{array}{l}\text { NZ\$210 (levies on licences and } \\
\text { fuel) }\end{array}$ \\
\hline
\end{tabular}

77 Australian Competition and Consumer Commission Second Insurance Industry Market Pricing Review (ACCC, Canberra, 2002) 87, Fig 3.10 CTP premiums for annual policies $<$ http://www.accc.gov.au $>$ (last accessed 24 November 2003). 
A comparison between Australia and New Zealand shows a similar picture with regard to the cost to employers of workers' compensation. ${ }^{79}$

\begin{tabular}{|c|c|c|c|c|c|c|c|}
\hline & Vic & NSW & SA & WA & Qld & Tas & NZ \\
& $\%$ & $\%$ & $\%$ & $\%$ & $\%$ & $\%$ & $\%$ \\
\hline $\begin{array}{c}\text { Average } \\
\text { levy/premium rate }\end{array}$ & 2.22 & 2.80 & 2.46 & 2.47 & 1.55 & 2.62 & 0.90 \\
\hline
\end{tabular}

\section{IPP COMMITTEE RECOMMENDATIONS}

\section{A Standard of Care}

The stringent time limits imposed on the Ipp Committee were adhered to. The Ipp Committee made 61 formal recommendations in its report. Some of these were quickly implemented. However, many have been ignored. The first recommendation was that there should be a national response, with a single statute enacted in each Australian jurisdiction. Instead, there have so far been two or three waves of legislation in each jurisdiction. Although the legislation does bear some similarity, there are differences between jurisdictions. Some of the differences are obviously significant. Others appear to reflect only preferences of individual parliamentary counsel in drafting. Only time - and costly litigation - will tell whether they are significant.

Some of the Ipp Committee's recommendations merely called for a restatement of the law of negligence as it had developed. In several instances the Committee was of the opinion that the law was satisfactory, but it had been misunderstood or misapplied. The Committee thought that a restatement in legislative form would obviate this. Some of the recommendations were to reinstate older law where modern interpretations were said to go too far. For example, under the test for foreseeability at the stage of breach of a duty of a care, the High Court had held that: ${ }^{80}$

[W]hen we speak of a risk of injury as being "foreseeable" we are not making any statement as to the probability or improbability of its occurrence, save that we are implicitly asserting that the risk is not one that is far-fetched or fanciful.

78 Mark Weaver and Steve McCormack "New Zealand's No-Fault Accident System" (2003) Emphasis 2.

79 Extracted from Heads of Workers' Compensation Authorities Comparison of Workers' Compensation Arrangements: Australia \& New Zealand (2003) 42 <www.hwca.org.au> (last accessed 20 November 2003)

80 Wyong Shire Council v Shirt (1980) 146 CLR 40, 47 Mason J. 
This statement has been applied in hundreds of cases, but, as we have seen, it has been seen as responsible for expansion of the law of negligence beyond its "proper" sphere. ${ }^{81}$ The Committee favoured its replacement by another word and deliberately chose the double negative "not insignificant". ${ }^{82}$ This has led to such gems of drafting as the following: ${ }^{83}$

(3) For the purposes of sub-section (1)(b) -

(a) insignificant risks include, but are not limited to, risks that are far-fetched or fanciful; and

(b) risks that are not insignificant are all risks other than insignificant risks and include, but are not limited to, significant risks.

One instance where the Committee recommended a substantive change was in the test for medical negligence. Doctors - and some other professionals - have been protected in England by the "Bolam test", which holds that the defendant's actions cannot amount to negligence if they complied with a practice regarded at the time as proper by a responsible body of opinion within the profession. ${ }^{84}$ This special protection for doctors was rejected in Australia in a series of High Court of Australia cases. In Rosenberg $v$ Percival, Gleeson CJ, referring to the decision in Rogers $v$ Whitaker, ${ }^{85}$ said: ${ }^{86}$

... [T] he relevance of professional practice and opinion was not denied; what was denied was its conclusiveness. In many cases, professional practice and opinion will be the primary, and in some cases it may be the only, basis upon which a court may reasonably act. But, in an action brought by a patient, the responsibility for deciding the content of the doctor's duty of care rests with the court, not with his or her professional colleagues.

In response to fears of those in the medical profession that this exposed them to findings of negligence with which they could not agree, the Ipp Committee recommended the reintroduction of the Bolam test, subject to certain modifications. ${ }^{87}$ However, it confined this to medical treatment. With regard to a doctor's duty to give advice, the Committee recommended a codification of the principles of Rogers $v$ Whitaker, as reaffirmed in Rosenberg $v$ Percival. ${ }^{88}$ While most jurisdictions

81 Spigelman, above $\mathrm{n} 6$.

82 Ipp Committee Report, above n 47, para 7.15.

83 Wrongs Act 1958 (Vic), s 49 (emphasis added).

84 It is derived from the charge to the jury by McNair $\mathrm{J}$ in Bolam v Friern Barnet Hospital Management Committee [1957] 1 WLR 582; [1957] 2 All ER 118 (QB).

85 Rogers $v$ Whitaker (1992) 175 CLR 479.

Rosenberg v Percival (2001) 205 CLR 434, 439 Gleeson CJ (emphasis in original).

87 Ipp Committee Report, above n 47, recommendation 3.

Ipp Committee Report, above n 47, recommendations 5-7. 
have adopted the former of these recommendations relating to the standard of care where professionals provide a service - again there are differences in wording which may or may not be important - and have also excluded the duty to warn from the modified Bolam test, ${ }^{89}$ only two have sought to codify the standard of care to be expected in relation to the giving of advice, using the Committee's terms of a "proactive" and a "reactive" duty. ${ }^{90}$

\section{B No Change}

Several of the recommendations of the Ipp Committee were for no change in the law. As we have already seen, it recommended that there should be no special protection for Good Samaritans. However, legislatures have gone ahead and given such protection. ${ }^{91}$ Similarly, the Ipp Committee did not deal at all with the sort of situation described above where a householder acts in purported self-defence against an intruder. Nevertheless, the Civil Liability Act 2002 (NSW) Part 7, for instance, affords complete protection to persons acting reasonably in self-defence according to their perception of the situation. Even if their response is unreasonable according to their perception, damages may only be awarded to the plaintiff in limited circumstances and not for non-economic loss. Where the plaintiff's criminal conduct constitutes an offence punishable by six months' imprisonment or more and it contributed to the injury or death, no damages may be awarded. ${ }^{92}$

On the other hand, on some issues not dealt with by the Committee, the legislatures have preserved the common law, thereby creating exceptions to the exceptions. For instance, the Civil Liability Acts often do not apply to a range of matters, including "where the injury or death concerned resulted from smoking or other use of tobacco products". ${ }^{93}$ These exceptions can hardly be a response to the call for a more principled approach.

\section{Damages}

The Ipp Committee made a number of recommendations for capping damages and introducing thresholds. In relation to non-pecuniary loss, it recommended a threshold of 15 per cent of a most extreme case and a cap of A $\$ 250,000 .{ }^{94}$ Legislatures have adopted different caps and thresholds, if any. The caps are generally much higher, for example in Victoria it is $\$ 371,380$ (indexed). ${ }^{95}$ The

89 See for example Civil Liability Act 2002 (NSW), s 50.

90 Civil Liability Act 2003 (Qld), s 21; Civil Liability Act 2002 (Tas), s 21.

91 Civil Liability Act 2002 (NSW), Pt 8; Law Reform Act 1995 (Qld), Pt 5; Civil Liability Act 1936 (SA), s 74; Wrongs Act 1958 (Vic), Pt VIA; Civil Liability Act 2002 (WA), Pt 1D; Civil Law (Wrongs) Act 2002 (ACT), s 5; Personal Injuries (Liabilities and Damages) Act 2003 (NT), s 8.

92 Civil Liability Act 2002 (NSW), ss 51-54.

93 Civil Liability Act 2002 (NSW), s 3B(1)(c).

94 Ipp Committee Report, above n 47, recommendations 47 and 48(a). 
Committee recommended capping damages for loss of earning capacity at twice average full-time adult ordinary time earnings. ${ }^{96}$ Most legislatures have imposed a higher cap here too, at least three times average weekly earnings. ${ }^{97}$

On the other hand, the Ipp Committee recommended that the discount rate remain at 3 per cent, and that an expert panel be appointed to recommend changes in the future. ${ }^{98}$ Instead most legislatures have moved to 5 per cent, so disadvantaging those in need of long-term care. ${ }^{99}$ In Tasmania, the rate remains incredibly high at 7 per cent. ${ }^{100}$

\section{Governmental Bodies}

The Ipp Committee recommended that the Wednesbury administrative law test ${ }^{101}$ be introduced in relation to the liability of government bodies. ${ }^{102}$ This would give such bodies a policy defence unless no reasonable body in that position could have made a decision such as that which the body made. Legislatures have adopted this recommendation with alacrity, going much further in some instances in order to protect the decisions of governmental bodies from subjection to the courts' views of negligence. ${ }^{103}$

The Committee saw this policy defence as providing adequate protection for highway authorities. The High Court of Australia had recently abolished the special immunity of highway authorities at common law. ${ }^{104}$ Although it was urged to reverse this decision, the Committee was not persuaded that there was a need to do so. ${ }^{105}$ Once again, legislatures disagreed and have all reinstated the immunity of highway authorities. ${ }^{106}$

96 Ipp Committee report, above n 47, recommendation 49.

97 For example, Civil Liability Act 2002 (NSW), s 12. However, the definition of average weekly earnings differs from jurisdiction to jurisdiction and the increase over the Ipp recommendation is not always as stark as it appears at first sight.

98 Ipp Committee Report, above n 47, recommendation 53.

99 For example Civil Liability Act 2003 (Qld), s 57.

100 Common Law (Miscellaneous Actions) Act 1986 (Tas), s 4.

101 See Associated Provincial Picture Houses Ltd v Wednesbury Corp [1948] 1 KB 223.

102 Ipp Committee Report, above n 47, recommendation 39.

103 See, for example, Civil Liability Act 2002 (NSW), Pt 5.

104 Brodie v Singleton Shire Council (2001) 206 CLR 512.

105 Ipp Committee Report, above n 47, para 10.5.

106 For example, Transport Act 1983 (Vic), Pt IIA. 


\section{E Mental Harm}

While the Ipp Committee was actually deliberating, the High Court of Australia expounded the law of negligence liability in relation to psychiatric injury ("nervous shock"), removing many of the limitations which it had previously been believed applied as a matter of law to such claims. ${ }^{107}$ The Ipp Committee recommended that this exposition of the law relating to duty of care in cases of mental harm be embodied in legislation, and be extended to apply also to consequential mental harm. ${ }^{108}$ On one point the High Court of Australia had been divided and the Committee chose what is arguably the minority view in recommending that a duty of care to avoid causing mental harm does not exist unless it is reasonably foreseeable that a person of "normal fortitude" would suffer psychiatric injury of some sort, though the plaintiff need not be such a person. ${ }^{109}$ In recommending that there be no recovery for mental harm that does not amount to a recognised psychiatric injury, ${ }^{110}$ the Committee urged the appointment of a panel of experts (including experts in forensic psychiatry and psychology) to develop guidelines, for use in legal contexts, for assessing whether a person has suffered a recognised psychiatric illness. ${ }^{111}$ There appears to have been no response to this recommendation, but the others have not only been adopted but extended, so that in many jurisdictions there may be no recovery in "three-party" situations unless the plaintiff witnessed the accident at the scene or was closely related to the person injured or endangered. ${ }^{112}$

\section{F False Perceptions}

As we have seen, the impetus for the establishment of the Ipp Committee and the legislative changes made to the common law was a perception that the law of negligence had become too plaintiff-friendly. However, change was already on its way from the courts themselves. In the paper that may be seen as starting the process, Spigelman CJ, after drawing attention to a couple of decades in which the courts had "stretched" both the law and the facts to enable plaintiffs to receive compensation, noted "a growing body of recent High Court decisions in favour of defendants [that] would have gone the other way if the trend had continued". ${ }^{113}$ A marked change in the attitude of the High Court of Australia occurred at the end of 1999. In personal injury cases, in the period $1987-99,80$ per cent (32 out of 40) could be categorised as pro-plaintiff. In the period 2000-03,

107 Tame v New South Wales; Annetts v Australian Stations Pty Ltd (2002) 211 CLR 317.

108 Ipp Committee Report, above n 47, recommendations 33-37.

109 See Joachim Dietrich "Nervous Shock: Tame v New South Wales and Annetts v Australian Stations Pty Ltd" (2003) 11 TLJ 11; Peter Handford "Psychiatric Injury: The New Era" (2003) 11 Tort L Rev 13.

110 Compare Van Soest v Residual Health Management Unit [2001] 1 NZLR 179 (CA).

111 Ipp Committee Report, above n 47, recommendation 33.

112 For example, Civil Liability Act 2002 (NSW), s 30.

113 Spigelman, above n 6. 
only 33 per cent (12 out of 36 ) could be similarly categorised. ${ }^{114}$ Even these latter figures underestimate the extent to which the common law fails to compensate, since in two of these twelve High Court pro-plaintiff decisions, although the decision on the law was pro-plaintiff, there were actually two plaintiffs, one of whom failed on the application of the law.

The change can be seen not so much in duty of care situations, but in the application of wellestablished principles at the breach stage. For example, take two cases involving injury in a recreational area. In Nagle $v$ Rottnest Island Authority, ${ }^{115}$ a young man who dived into the sea and struck his head on a rock recovered damages; whereas in Romeo $v$ Conservation Commission of the Northern Territory ${ }^{116}$ a young woman who fell over the edge of cliff at night at a beauty spot failed in her action. The common law continues to be a lottery so far as recovery of compensation is concerned. Winners have become decidedly fewer.

If the common law fails as a compensatory mechanism, as Woodhouse long ago recognised, can it be said to serve a purpose in raising standards of care in the community? In the earlier era the High Court of Australia was concerned to recognise raised standards generally and to impose them on individuals who disregarded them. In Bankstown Foundry Pty Ltd v Braistina, ${ }^{117}$ for example, although the Court repudiated a dictum in the Court below that the common law of employer's liability had "moved close to the borders of strict liability", three judges said: ${ }^{118}$

... [W] hat reasonable care requires will vary with the advent of new methods and machines and with changing ideas of justice and increasing concern with safety in the community. ... What is considered to be reasonable in the circumstances of the case must be influenced by current community standards. In so far as legislative requirements touching industrial safety have become more demanding upon employers, this must have its impact on community expectations of the reasonably prudent employer.

The other two judges in the case said: ${ }^{119}$

Contemporary decisions about what constitutes reasonable care on the part of an employer towards an employee in the running of a modern factory are in sharp conflict with what would have been considered reasonable care in a nineteenth century workshop and, for that matter, reflect more

114 See Harold Luntz "Torts Turnaround Downunder" (2001) 1 OUCLJ 95; Harold Luntz "Turning Points in the Law of Torts in the Last 30 Years" (2003) 15 ILJ 1. The figures in the text of the present paper have been updated to the end of 2003; Harold Luntz "Round-up of Cases in the High Court of Australia in 2003" (2004) 12 TLJ 1 ["Round-up of Cases in the High Court of Australia in 2003"].

115 Nagle v Rottnest Island Authority (1993) 177 CLR 423.

116 Romeo v Conservation Commission of the Northern Territory (1998) 192 CLR 431.

117 Bankstown Foundry Pty Ltd v Braistina (1986) 160 CLR 301.

118 Bankstown Foundry Pty Ltd v Braistina, above n 117, 308-9 Mason, Wilson and Dawson JJ.

119 Bankstown Foundry Pty Ltd v Braistina, above n 117, 313-14 Brennan and Deane JJ. 
demanding standards than those of 20 or 30 years ago. While it is true that that has, in part, been the consequence of the elucidation and development of legal principle, it has, to a greater extent, reflected the impact, upon decisions of fact, of increased appreciation of the likely causes of injury to the human body, of the more general availability of the means and methods of avoiding such injury and of the contemporary tendency to reject the discounting of any real risk of injury to an employee in the assessment of what is reasonable in the pursuit by an employer of pecuniary profit.

This case involved a back injury where the worker failed to use a hoist that was available to him. The High Court of Australia upheld a finding that the employer was negligent in failing to prescribe the use of the hoist and that the degree of the worker's contributory negligence was only 10 per cent. In contrast, in the similar but more recent case of Liftronic Pty Ltd $v$ Unver, ${ }^{120}$ the High Court of Australia restored a jury verdict attributing 60 per cent contributory negligence to the worker, which the New South Wales Court of Appeal had set aside as perverse. Two members of the majority in the High Court of Australia said:121

The different view of the majority of the Court of Appeal from the jury's view is probably indicative of too ready a judicial inclination to absolve people in the workplace from the duty that they have to look out for their own safety which will often depend more, or as much, upon their own prudence and compliance with directions, as upon any measures that a careful employer may introduce and seek to maintain.

So too in Woods $v$ Multi-Sport Holdings Pty Ltd, ${ }^{122}$ a majority of the High Court of Australia absolved the organisers of a game of indoor cricket from negligence in failing to warn of the risk of eye injuries in the sport, or to provide helmets or other protection against the risk. The majority saw risk as something which players readily assumed themselves. ${ }^{123}$ It was left to a minority of the Court to point to the high level of injuries resulting from recreational activities of all kinds and the need to set standards in order to reduce such injuries. ${ }^{124}$

Similarly, in the area of motor accidents, the Court has recently insisted on maintaining the system as one based on fault. In Derrick $v$ Cheung, ${ }^{125}$ a 21 -month-old child who ran into a busy road was run down by a motorist travelling at a moderate speed. The trial judge nevertheless held the defendant negligent on the basis that if she had been travelling more slowly she could have

120 Liftronic Pty Ltd v Unver (2001) 179 ALR 321; [2001] HCA 24.

121 Liftronic Pty Ltd v Unver, above n 120, para 60 Gummow and Callinan JJ.

122 Woods v Multi-Sport Holdings Pty Ltd (2002) 208 CLR 460.

123 Compare Agar v Hyde (2000) 201 CLR 552 (no duty of care to avoid causing quadriplegia from rugby).

124 For a discussion of the case, see Kylie Burns "It's Just Not Cricket: The High Court, Sport and Legislative Facts" (2002) 10 TLJ 234.

125 Derrick v Cheung (2001) 181 ALR 301 (HCA). 
avoided the accident. This decision was upheld in the New South Wales Court of Appeal by a majority, who commented that no moral blame attached to the defendant driver. A unanimous High Court of Australia insisted on proof of negligence: ${ }^{126}$

The appeal to this Court must be upheld. There was no basis upon which any finding of negligence on the part of the appellant could be made. ... [T] he test remains whether the plaintiff has proved that the defendant, who owed a duty of care, has not acted in accordance with reasonable care. To offer, as the majority in the Court of Appeal did, its consolation that the appellant does not bear any moral, as distinct from legal, responsibility for what occurred is to obscure that issue.

In other motor accident cases, the search for fault occupies the minds of the most gifted and highly paid judges in the country, sometimes 10 years after the event, even though the standard of care is not in issue and it all boils down to finding on which side of the road the collision occurred. $^{127}$

\section{CONCLUSION}

All the defects in the common law insurance system that the Woodhouse Royal Commission found more than 30 years ago are alive and well in Australia. Under this system, the receipt of compensation for personal injury is a lottery. Only a small proportion of incapacitated people recover damages. When the common law system does deliver benefits it is slow in doing so, often taking many years to resolve claims. The cost of providing the benefits is horrendously expensive, since determining who is to receive compensation, being dependent on proof of fault, absorbs huge amounts of time for lawyers, judges and many other professionals.

There is little evidence that holding people liable for negligence acts as a deterrent to careless conduct and improves safety. On the other hand, the perception that one might be sued discourages worthwhile activity unless insurance against liability can be obtained at an affordable cost. Insurers themselves do little to encourage safety. Public authorities do much more to reduce accidents through public education, the provision of technology, such as "booze buses" and speed cameras, to aid criminal law enforcement, and the elimination of danger in the environment, such as by improving roads and prohibiting the sale of dangerous products. The standard-setting role of the courts has been largely abrogated and is more effectively achieved through regulations requiring compliance with standards promulgated by other bodies.

Finally, lump-sum awards of damages are dependent on unpredictable future events. Even if the assumptions on which they are made do prove accurate, the high discount rates now prescribed by

126 Derrick v Cheung, above n 125, para 13 Gleeson CJ, Gaudron, Kirby, Hayne and Callinan JJ.

127 See for example Fox v Percy (2003) 214 CLR 118; [2003] HCA 22. See further "Round-up of Cases in the High Court of Australia in 2003", above n 114, 6-10. 
legislation mean that the damages are unlikely to provide full compensation for the needs of the seriously injured.

The recent waves of tort law reform in Australia will not only exacerbate many of these problems, but they have also made the common law completely unprincipled. 
